\title{
Hydrographic containment of a spawning group of plaice in the Southern Bight of the North Sea
}

\author{
D. H. Cushing
}

198 Yarmouth Rd, Lowestoft, Suffolk NR32 4AB, United Kingdom

\begin{abstract}
The spawning group of plaice Pleuronectes platessa $L$. which spawns in the Southern Bight of the North Sea is relatively isolated from neighbouring groups. The adults migrate to a fixed spawning ground at a fixed season by selective tidal stream transport. The larvae drift in the lower part of the water column from the spawning ground to the fixed nursery ground in the Wadden Sea. Such mechanisms allow the group to be retained within a part of the Southern North Sea.
\end{abstract}

\section{INTRODUCTION}

The hydrographic containment of a fish stock was initially defined as the seasonal use of currents by fish populations (Cushing 1968). It was based on the triangle of migration (Harden Jones 1968), the circuit by which the stock maintains its identity from generation to generation (Fig. 1). He wrote: 'the young stages leave the spawning ground at $\mathrm{A}$ for the nursery ground at $B$ : from the nursery ground, the juveniles recruit to the adult stock on the feeding grounds at $C_{i}$ and the mature and ripening fish move from the feeding grounds back to the spawning grounds at $\mathrm{A}$. Then as spents they return to the feeding ground ... the young stages drift with the current to the nursery ground; the spawning migration from $\mathrm{C}$ to $\mathrm{A}$ is against the current and the spents return to the feeding ground with the current.'

Physical oceanographers can now describe the movements of water in coastal regions in some detail. Do fish stocks need hydrodynamic structures such as fronts or eddies to retain them within a region? This review sets out to show that, provided there is a tidal system or even perhaps a regular current, fish stocks can make use of it to remain within such a region with the use of behavioural mechanisms alone.

There are many spawning groups of plaice Pleuronectes platessa $\mathrm{L}$. in the seas around the British Isles (Fig. 2a, after Harding et al. [1978], which com- prises all material published to that date). In the southern North Sea 3 spawning groups are usually recognized: German Bight, Flamborough and Southern Bight (but there may be a fourth immediately south of the Dogger Bank, which de Veen [1978], called the Transition Area); there is another in the eastern English Channel which is as large as that in the Southern Bight (Harding et al. 1978). (The locations of these and other places mentioned are shown in Fig. 8) The spawning groups in the southern North Sea and eastern English Channel form the present unit of management (i.e. the area for which the annual quota, or Total Allowable Catch, is calculated). In this paper the hydrographic containment of the Southern Bight group of spawners only is described.

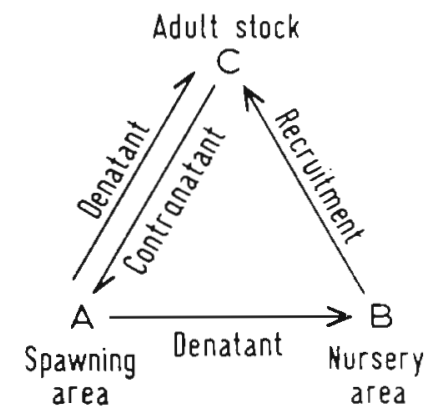

Fig. 1. The migration circuit (Harden Jones 1968) 


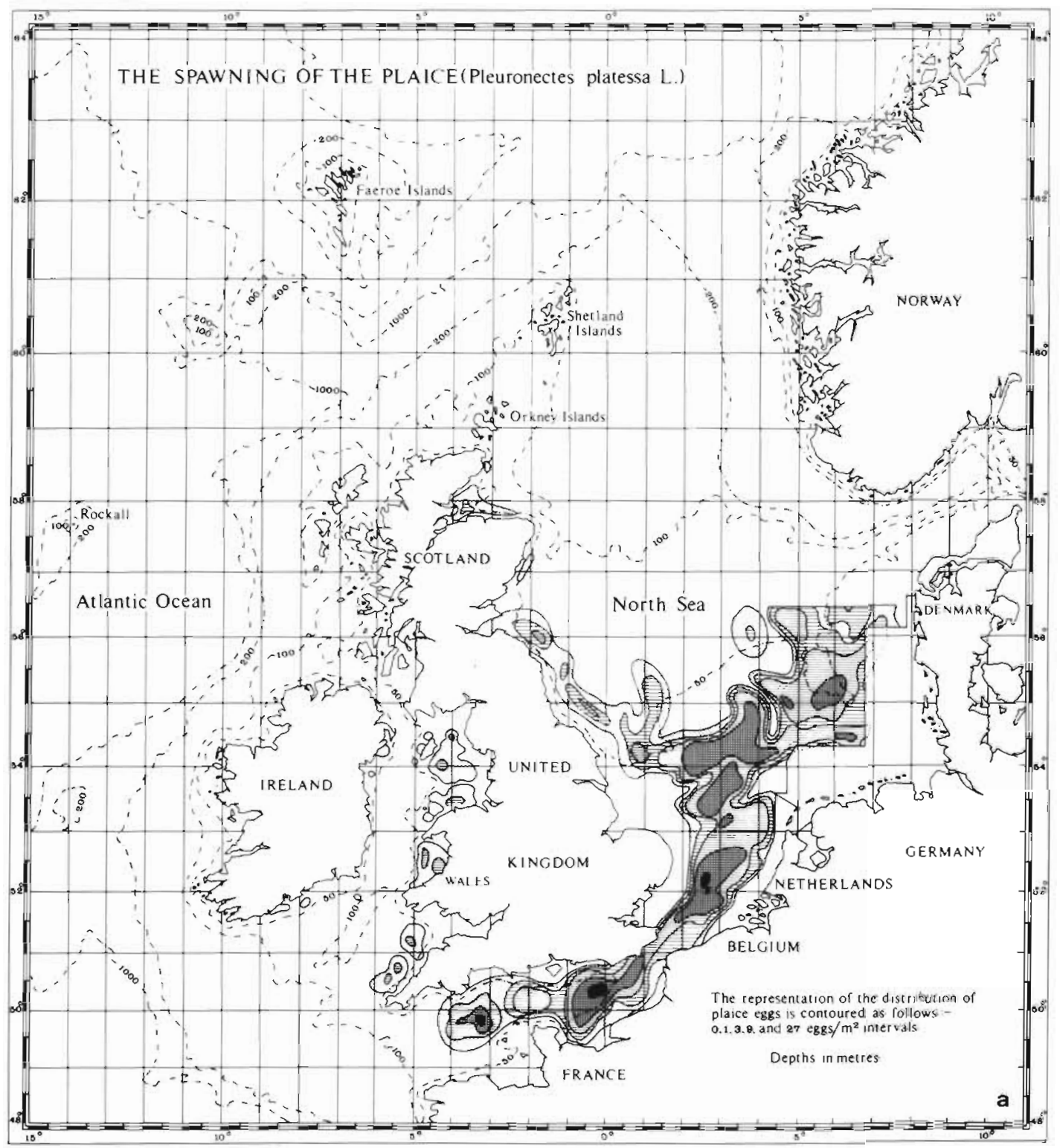

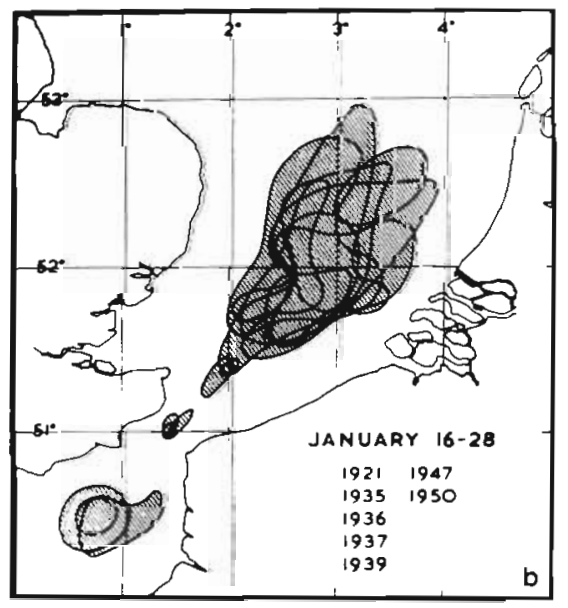

Fig. 2. Pleuronectes platessa. (a) Distribution of stage 1a eggs in the waters around the British Isles for all cruises up to 1971 (Harding et al. 1978). Contours are at 0, 1, 3, 9 and 27 eggs $\mathrm{m}^{-2}$ (b) Distrubution of stage 1 eggs in the Southern Bight of the North Sea between 16 and 28 January (time of peak spawning) for 7 yr between 1921 and 1950 (Simpson 1956), contoured at $1 \mathrm{egg} \mathrm{m}^{-2}$ 


\section{SPAWNING}

Cushing (1969) showed that the mean peak date of spawning of this group of plaice, sampled from time to time by egg surveys throughout the spawning season between 1911 and 1967, was 19 January, with a standard deviation of less than $1 \mathrm{wk}$ (and a standard error of ca 2 d). Fig. 2b (Simpson 1956) shows the distributions of stage 1 eggs between 16 and 28 January for $7 \mathrm{yr}$ between 1921 and 1950; the distributions of spawning in fact remained the same until the last series of plaice egg cruises in 1971. Fig. 2a, contoured at 0 to 1 egg $\mathrm{m}^{-2}$, shows continua of spawning between the major

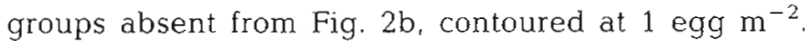
The plaice of the Southern Bight spawn at the same time and position each year.

Fig. 3 shows the temporal distributions of spawning in spring (sampled in numbers of eggs $\mathrm{m}^{-2}$ ) of 7 species: plaice Pleuronectes platessa L., cod Gadus morhua L., dab Limanda limand L., flounder Platichthys flesus L., sandeel Ammodytes spp., whiting Merlangius merlangus L. and bib Trisopterus luscus L. in the Southern Bight of the North Sea (after Harding et al. 1978). On the same figure is shown the progress of the spring outburst as sampled (in 'greenness', the conventional way of estimating phytoplankton roughly from the plankton recorder samples; Gieskes \& Kraay [1977] showed that the estimate of 'greenness' was a reasonable measure of net phytoplank-

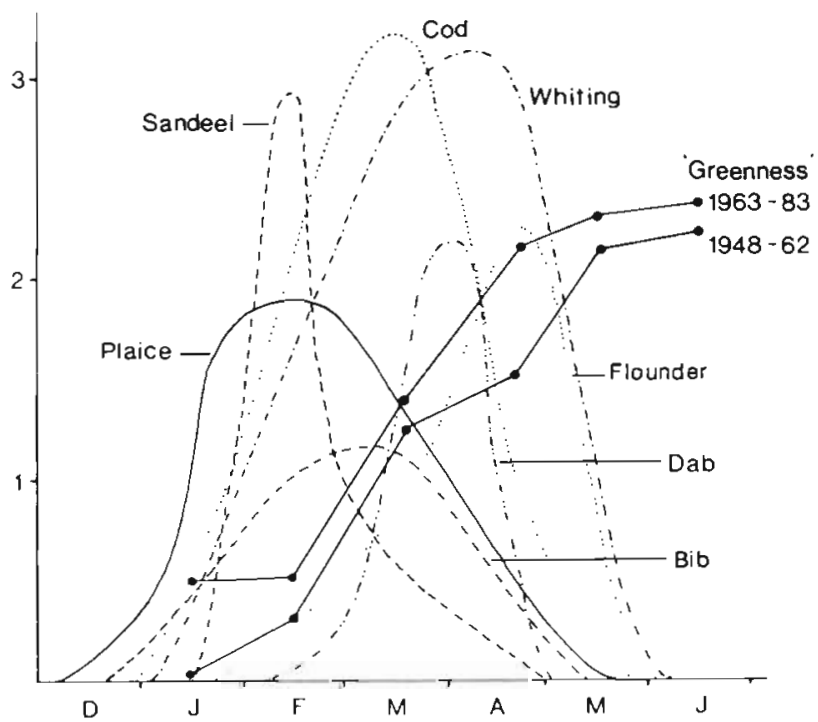

Fig. 3. Spring distributions of spawning of 7 species in the Southern Bight of the North Sea (after Harding et al. 1978). Figure also shows the spring outburst as 'greenness' in squares $O v$ and $O w$ (in the west and east of the Southern Bight, respectively) in the Continuous Plankton Recorder Network, averaged for the periods 1948 to 1962 and 1963 to 1983 (reproduced with permission of the Director, Plymouth Marine Laboratory, UK) ton). The samples were taken in the Southern Bight for the 2 squares between $52^{\circ} \mathrm{N}$ and $52^{\circ} 30^{\prime} \mathrm{N}$, grid references Ov(west) and Ow(east), of the Continuous Plankton Recorder Network averaged for 2 periods, 1948 to 1962 and 1963 to 1983 (I am grateful to Dr Brian Bayne of the Plymouth Marine Laboratory, UK, for permission to use this material). All of the 7 species release their eggs before the spring outburst so that when the larvae hatch $3 \mathrm{wk}$ to 1 mo later, there is food available. Plaice and sandeel larvae feed mostly on Oikopleura spp. (which themselves feed on phytoplankton); most of the other species feed on nauplii and copepodites arising from the spring outburst. The larvae hatched up to a month after the eggs are laid have much opportunity to match their production to that of their food as the secondary production follows the spring outburst (Cushing 1973, 1975, 1982).

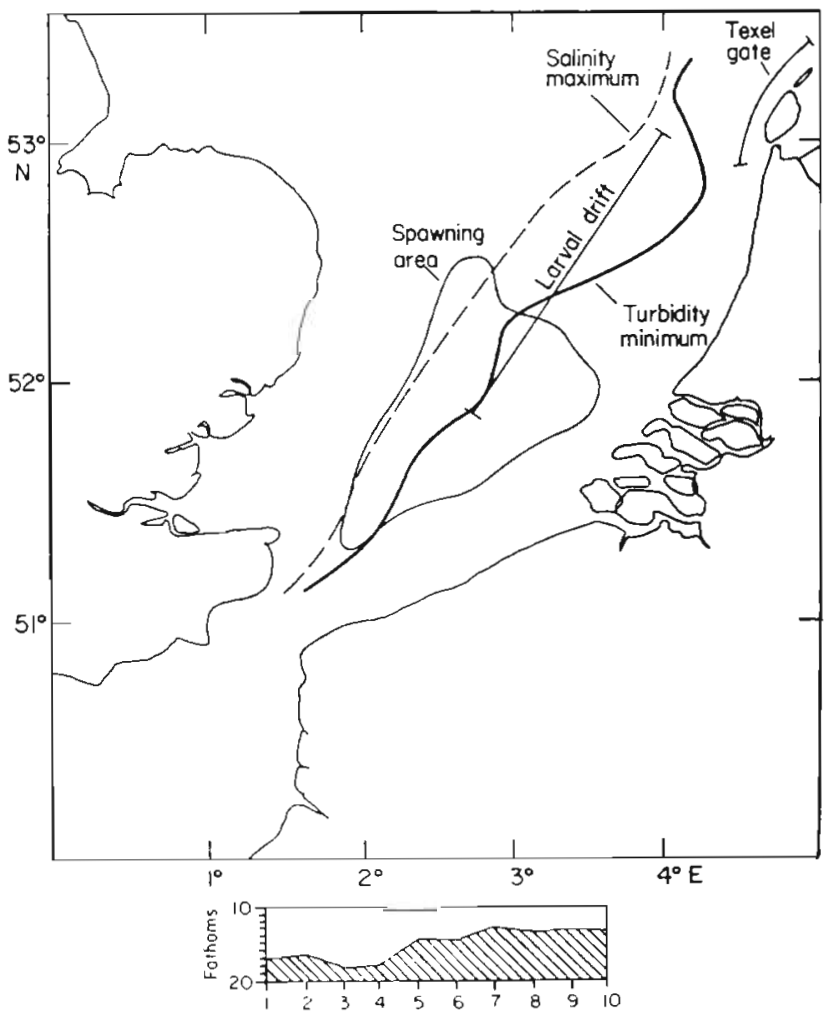

Fig. 4. Pleuronectes platessa. Drift of plaice larvae northeasterly in the Southern Bight of the North Sea from the spawning ground (Cushing 1972) in water of maximum salinity and minimum turbidity towards shallower water where production starts earlier. Below: decrease in depth (units of $10 \mathrm{n}$ mile) along the course northeasterly shown as the larval drift labelled between 2 bars

\section{LARVAL DRIFT}

Fig. 4 shows the larval drift of plaice northeasterly from the spawning ground (Cushing 1972). The larvae 
drift in the zone of maximum salinity and minimum turbidity, at the centre of the residual drift. On this course, the water shallows from 40 to $20 \mathrm{~m}$ i using estimates of compensation depth, critical depth and transparency, Cushing (1972) showed that production would start earlier in shallower and clearer water. Thus, the plaice larvae are caried towards this production.

Dietrich (1954) described a mechanism by which the

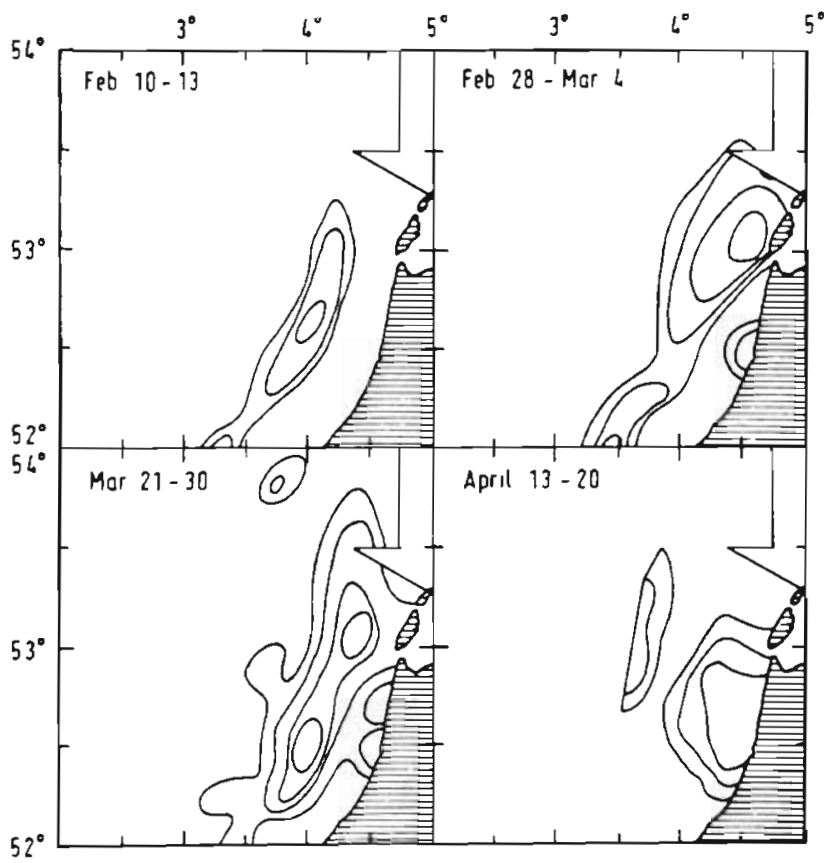

Fig. 5. Pleuronectes platessa. Distribution of metamorphosed plaice on the seabed off Texel Is. and the coast of the Netherlands (Harding et al. 1978)

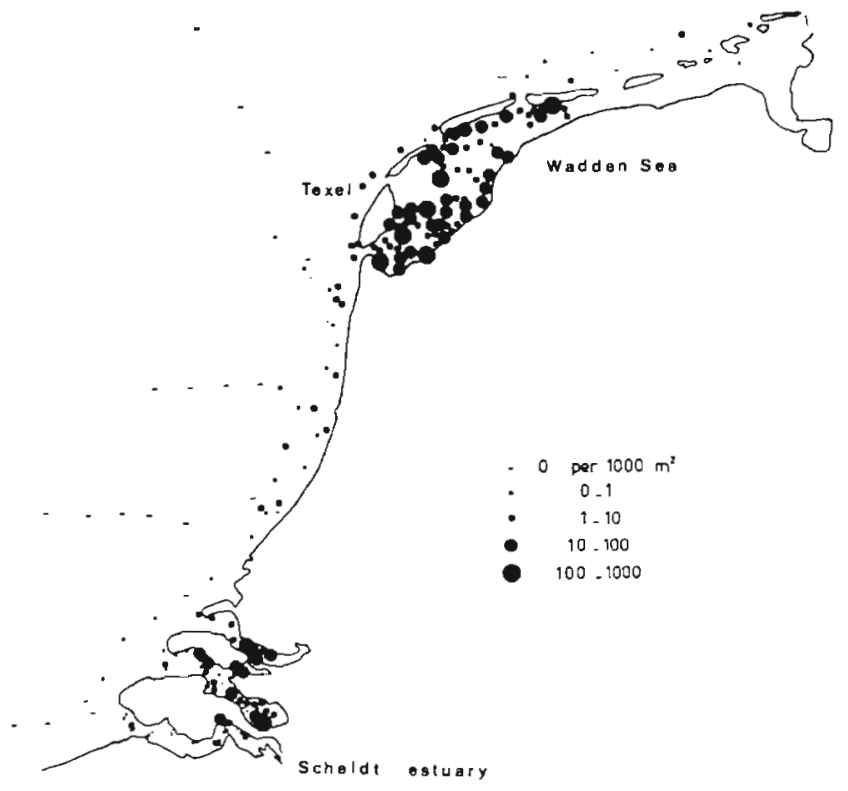

Fig. 6. Pleuronectes platessa. Distribution of 0-group plaice on their nursery ground in the Wadden Sea, on the north coast of the Netherlands (Zijlstra 1972) larvae might enter the Dutch coastal water, which is itself separated from the central water of the Southern Bight by a sharp salinity boundary. When the tidal streams flow parallel to the coastal water boundary, there is a component of offshore flow at the surface for a period of about an hour and an inshore flow at depth; I called it the Texel Gate (Cushing 1972). Harding \& Talbot (1973) showed that the larvae live in the lower part of the water column. However, Visser $(1971,1977)$ showed that Dietrich's mechanism may become less effective under strong winds such as those from the north with long fetch (Dickson \& Reid 1983). The larvae pass through the entrances between the Friesian Is. to the Wadden Sea. In the main, the larvae metamorphose at settlement on the nursery ground, but many larvae of the 1963 year class were drifted to some distance north of the Texel Gate (Beverton \& Lee 1965, Harding \& Talbot 1973). Thus, there is a possibility that larvae spawned in the Southern Bight are drifted to the German Bight nurseries, but perhaps infrequently.

\section{NURSERY GROUND}

Fig. 5 shows the distribution of settled plaice larvae on the sea bed as sampled with an Agassiz trawl (Harding et al. 1978). Creutzberg et al. (1978) showed that the late stage plaice larvae move into the entrance of the Wadden Sea by selective tidal stream transport (which I shall describe below for adults). Fig. 6 shows the distribution of 0 -group plaice on their nursery ground on the Wadden Sea in the northern Netherlands (Zijlstra 1972). Some 0-group plaice are found in the Scheldt estuary (Rijnsdorp \& van Stralen 1982) which may in fact come from the spawning ground in the eastern English Channel. Zijlstra (1972) showed that although some 0-group plaice were found on the open beaches, the great majority lived in the Wadden Sea. Dietrich said that there were only 2 entrances by his mechanism through the boundary between the coastal waters and those of the Southern Bight coastal waters off Texel Is. and off the Friesian Is. However, once within the coastal water, the larvae probably enter the Wadden Sea by all entrances. The plaice have established a larval drift from spawning ground to nursery ground and, by migrating downwards in the water column, they have exploited the hydrodynamic mechanism to complete the migration.

\section{MIGRATION FROM NURSERY GROUND TO FEEDING GROUND}

Fig. 7 shows the Leman-Haaks line of stations from which samples of immature plaice of ages 1 to 5 yrs 
Fig. 7. The Leman-Haaks line of stations in the Southern Bight, the data from which Beverton \& Holt (1957) described an offshore diffusion by immature plaice

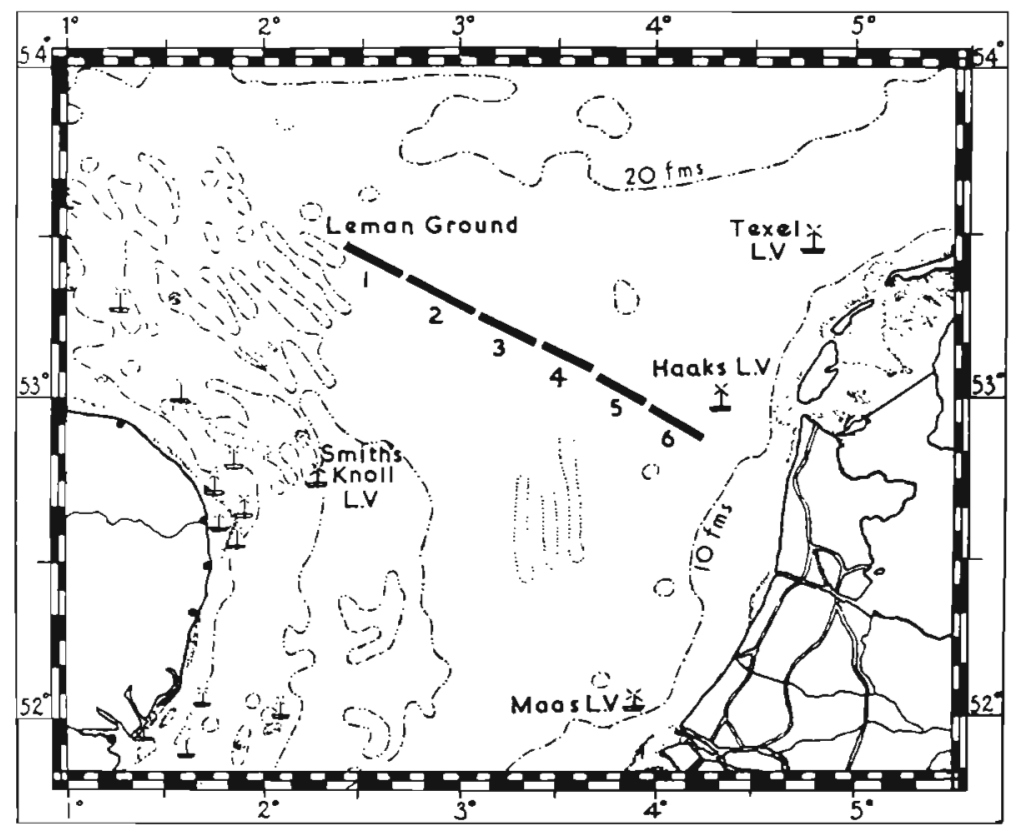

were taken each month by trawl for many years between the first and second world wars. Beverton \& Holt (1957) used this material to describe the offshore movement from the Dutch coast quite properly as a diffusion. As the fish grow older and bigger they are found in deeper water (Heincke 1913).

Harden Jones (1968) analyzed results from early tagging experiments in the first decade of the century (in Graham 1956) and showed that mature adults and spents both made their migrations in the western part of the Southern Bight. But the first time spawners came from the northeast, a result confirmed by Rauck (1977). De Veen $(1961,1962)$ tagged fish on spawning grounds in the German Bight and off the Yorkshire coast (NE England). Of the recoveries on these grounds in the following year only 1 to $2 \%$ strayed to another and none to that in the Southern Bight (Fig. 8). Rauck (1977) found that of plaice tagged on the German Bight spawning ground in the first quarter of the year, 1 out of 50 recovered in the same quarter in subsequent years appeared in the Southern Bight; but 2 out of 20 were taken there in the last quarter of the year. De Veen \& Boerema (1959) found that the diameters of the otolith nuclei in German Bight and Southern Bight plaice were quite different, those in the latter being larger; this implies that the 2 groups grew on different nurseries at distinct times. De Veen (1978) distinguished 4 sub-populations: Southern Bight, German Bight, Transition Area and Flamborough; tagged fish were released on the 4 spawning grounds and were recaptured 4 to 6 mo later. The centres of density moved about 100 miles; fish from Flamborough moved as far north as Aberdeen (Scotland), from the German Bight as far north as the Skagerrak, but those from the
Southern Bight did not move north of the Dogger Bank. The fish of the 4 groups live on distinct but overlapping feeding grounds and the 4 spawning groups are isolated from each other to quite a marked degree; but the low degree of exchange from year to

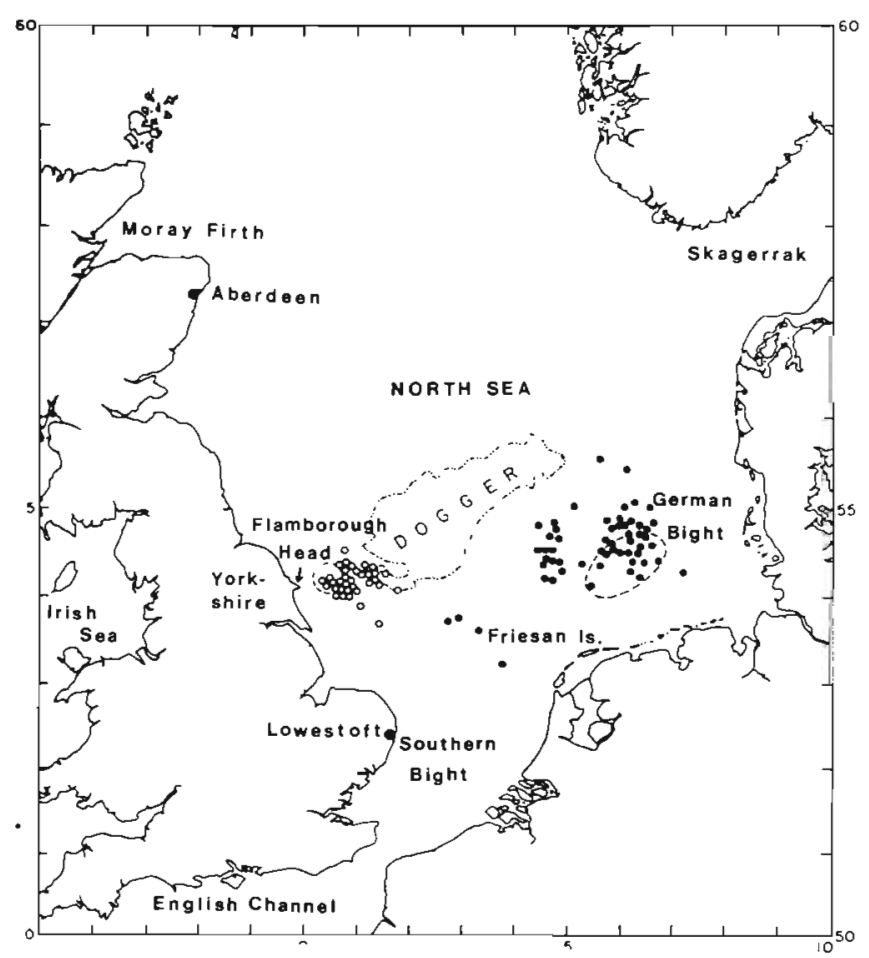

Fig. 8. Pleuronectes platessa. Recovery, 1 yr later, of plaice tagged on their spawning grounds, German Bight ( $\bullet$ ) and Flamborough (O). None was recovered on the Southern Bight spawning ground (de Veen 1962) and the proportions taken on a spawning ground other than that on which they were tagged are low 
year and between generations is probably great enough to prevent genetic differentiation.

\section{SPAWNING MIGRATION}

The plaice migrate to their spawning ground by selective tidal stream transport. That is, fish stay on the seabed during one tide and migrate up into the midwater on the next. In this way the fish can travel for some distance quite quickly in tidal waters. The process, discovered by Creutzberg (1961) in elvers and confirmed by Creutzberg et al. (1978) for plaice larvae, was established by Harden Jones and his colleagues (Harden Jones et al. 1978, Harden Jones 1980, 1984a, b) for plaice with the use of the sector scanning sonar. The transducer could be rotated through $90^{\circ}$ to search in the vertical dimension. Transponders at $300 \mathrm{kHz}$ (Mitson \& Storeton-West 1971) were attached to individual plaice and their movements were tracked for up to $82 \mathrm{~h}$.

Fig. 9 shows one series of observations (Greer Walker et al. 1978), the depth distribution of an acoustically tagged fish for 3 tides off Lowestoft (E England); on the northbound tide the plaice is in midwater and on the southbound one it stays on the seabed, and in $21 / 2$ tides the fish moved $25 \mathrm{n}$ miles to the north. Table 1 summarizes the information from a single fish followed for 5 tidal periods.

The speed over the ground allows the fish to migrate quickly. More generally, maturing fish migrate towards the south using selective tidal stream transport by staying on the sea bed on the northbound tide and spent fish return towards the north using the same mechanism but staying on the sea bed on the southbound tide. In view of this more general statement, the 2 fish whose movements are shown in Fig. 9 and Table 1 were probably spent. The 2 distinct migrations were confirmed by a series of midwater trawl hauls on consecutive northerly and southerly tides. In autumn, on the southerly migration of maturing fish, the greatest
Table 1 Pleuronectes platessa. Speed over the ground, direction of tide, and position in the water column for a plaice under continous observation with the sector scanner

\begin{tabular}{|c|c|c|c|}
\hline $\begin{array}{l}\text { Time } \\
\text { (GMT) }\end{array}$ & $\begin{array}{c}\text { Speed over } \\
\text { the ground } \\
\left(\mathrm{cm}^{-1} \mathrm{~s}\right)\end{array}$ & $\begin{array}{c}\text { Direction } \\
\text { of } \\
\text { tide }\end{array}$ & $\begin{array}{l}\text { Position in } \\
\text { water column }\end{array}$ \\
\hline $10: 00-13: 00 \mathrm{~h}$ & 80 & North & Midwater \\
\hline $13: 00-19: 00 \mathrm{~h}$ & 9 & South & On bottom \\
\hline $19: 00-02: 00 \mathrm{~h}$ & 89 & North & Midwater \\
\hline $02: 00-07: 00 \mathrm{~h}$ & 8 & South & On bottom \\
\hline $07: 00-12: 30 \mathrm{~h}$ & 115 & North & Midwater \\
\hline
\end{tabular}

catches were made on southbound tides and in winter, on the northerly migration of the spent fish, the greatest catches were made on the northbound tides. If the adult migrations take place in the western part of the Southern Bight, as suggested by Harden Jones (1968), the maturing fish move south on the flood and the spents move north on the ebb. Such are the spawning migrations; on the feeding grounds, however, the fish rise into midwater at night and return to the seabed in daylight and do not use selective tidal stream transport. Hence they do not migrate but may disperse as diel and tidal rhythms move into and out of phase with each other.

Greer Walker et al. (1978) compared midwater tracks with current meter observations by a simple vector analysis and found that the fish maintained consistent headings for periods of up to $2 \mathrm{~h}$. A compass tag was constructed (Mitson et al. 1982) transponding at 300 $\mathrm{kHz}$ to the sector scanning sonar in each of 8 sectors. Fig. 10 shows the averaged headings for $2 \frac{1}{2} h_{i}$ the fish moved with the tide and maintained a steady heading to the southeast. But, more generally, it can be seen from the compass tag results that the plaice do not maintain a heading without periodic contact with the sea bed. Harden Jones (1984b) has suggested that the labyrinth could provide a limited facility for inertial

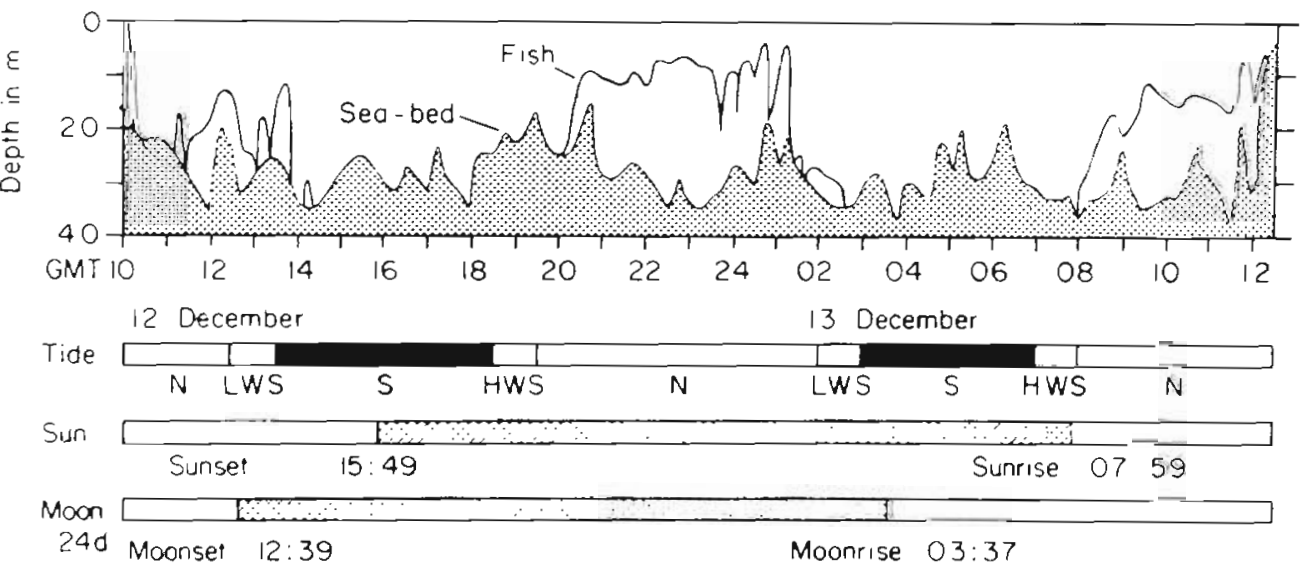

Fig. 9. Pleuronectes platessa. Selective tidal stream transport of a plaice in the southern North Sea observed with an acoustic tag trans. ponding to a sector scanning sonar at $300 \mathrm{kHz}$. The fish remained on the seabed during the southbound tide (S) but swam in midwater on the northbound one (N) (Harden Jones et al. 1978). LWS: low water slack: HWS high water slack 
Fig. 10. Pleuronectes platessa. Results of compass tag readings: tagged fish showed a fairly constant average heading to the southeast i.e. the fish swam with the tide and a little faster than the tidal stream (Harden Jones 1984a); OB: fish was observed to be off the bottom; JOB: just off the bottom

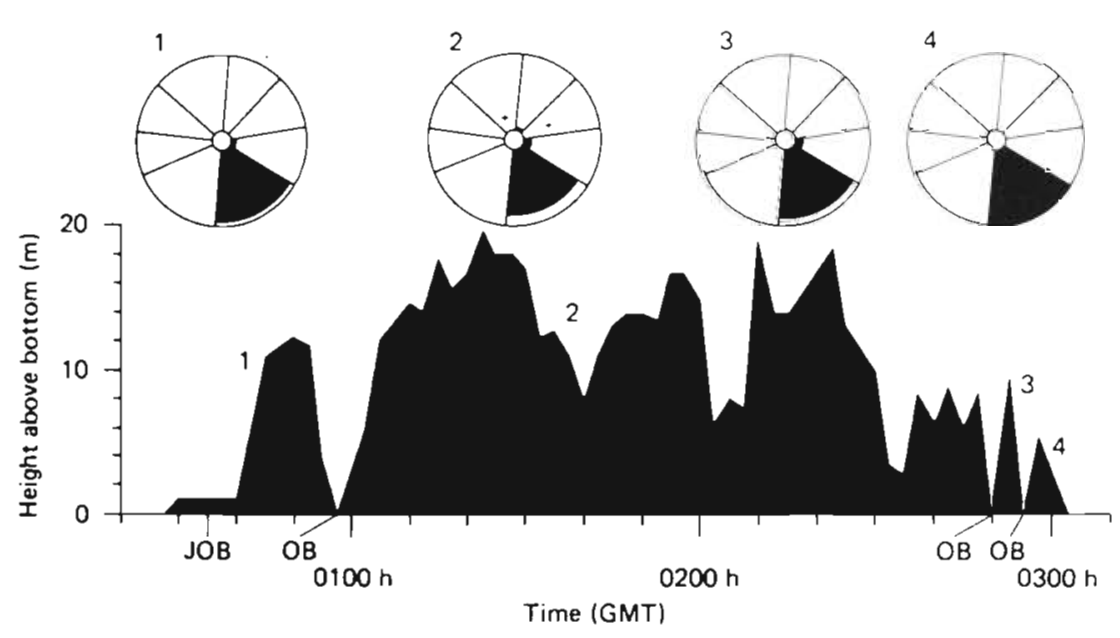

navigation corrected by fairly frequent excursions to the sea bed to make contact with the sand waves, which lie across the tidal streams.

Harden Jones et al. (1978) drew a picture of tidal stream paths in the North Sea, by connecting adjacent lines of maximum tidal flow (Fig. 11). From the figure, the fish in the Southern Bight would be expected to follow spawning migrations distinct from those in the German Bight provided that they fed in summer south of the Dogger and west of $3^{\circ} 30^{\prime}$ E. Fig. 12 (Arnold \& Cook 1984) shows simulated migration tracks in the Southern Bight constructed by starting migrations by selective tidal stream transport at selected points, and linking the tidal stream paths to make a continuous

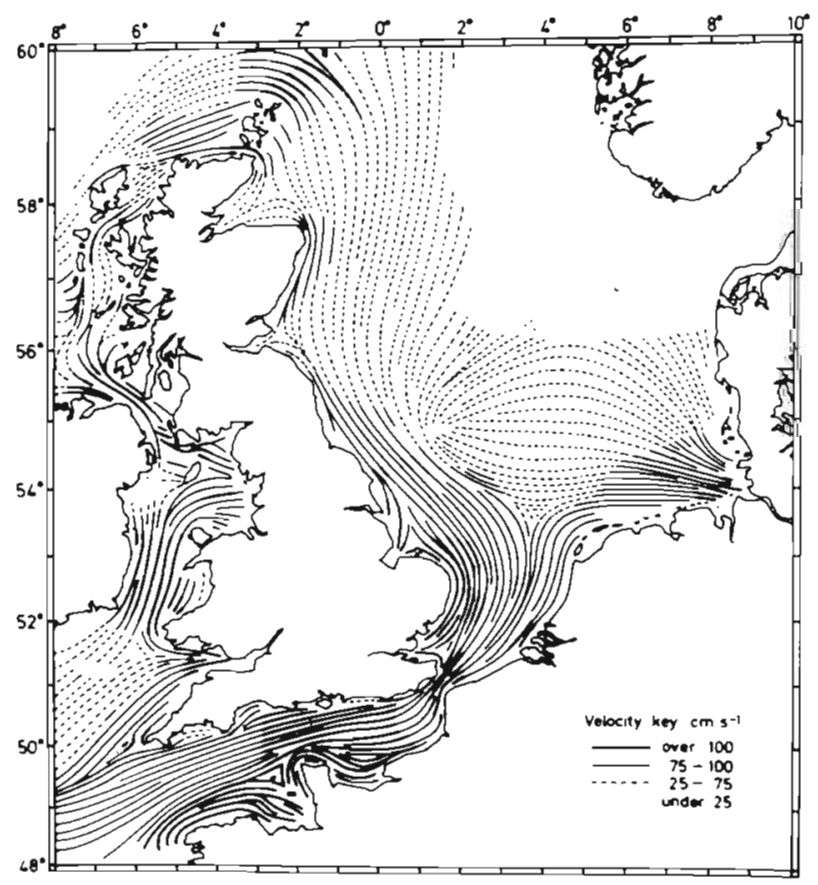

Fig. 11. Tidal stream paths in the North sea made by connecting a sequence of paths along tidal ellipses (Harden Jones 1984b) track. The 3 centres of spawning are shown as black circles. There is an amphidromic point in the centre of Southern Bight, so in the west at the flood, the tide flows to the south and in the east at the flood, it flows to the north. Tracks C and D show the southerly movement on the flood from the north in the western part of the Southern Bight as suggested above by Harden Jones (1968); further, Track G shows the direction from which the first time spawners come, moving south on the ebb. Some of Rauck's (1977) tag results suggest that some adults migrate on the continental side of the Southern Bight. Track F shows a migration into the German Bight, as suggested from Fig. 11; Tracks F and $\mathrm{G}$ go in opposite directions presumably because one used the flood and the other the ebb. This might well explain why the Southern Bight and German Bight spawning groups appear to have become isolated from each other.

De Veen (1978) described the results of tagging experiments in which fish were displaced from one

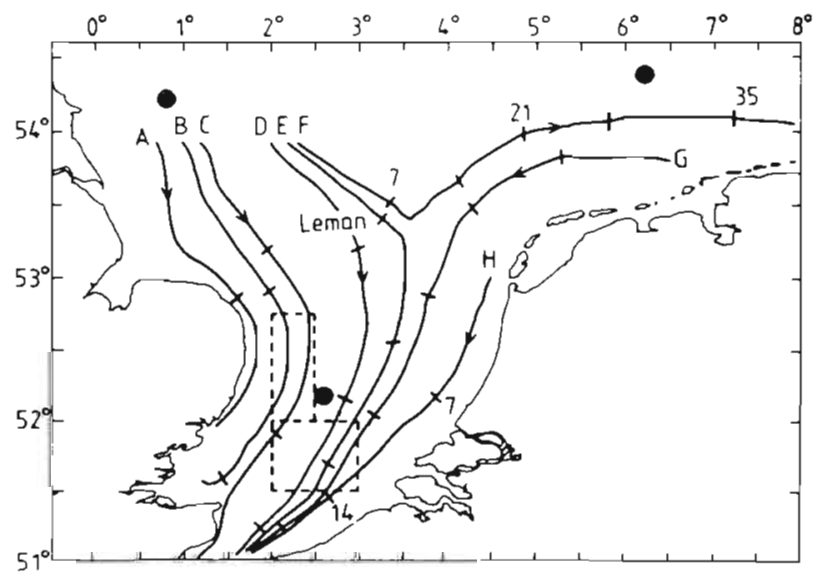

Fig. 12. Simulated tracks of southerly migration based on tidal stream paths and selective tidal stream transport from 6 points of origin, A to F (Arnold \& Cook 1984); the 3 black circles show centres of spawning 
spawning ground to another during the spawning season. After 4 to $6 \mathrm{mo}$, the distribution of recoveries showed a distinct tendency to return towards the original spawning ground, if with a broad spread. Indeed, the centre of distribution after 1 yr had moved half way across the North Sea from the German Bight to Flamborough. This provides some evidence for homing, but the mechanism remains unknown.

As the fish mature, they migrate southwards to the spawning ground in the Southern Bight, perhaps with some degree of homing. With selective tidal stream transport plaice can migrate from the Dogger Bank to the spawning ground in about 2 or $3 \mathrm{wk}$. They spawn at about the same position each year between December and March with a peak date on 19 January. Eggs and larvae are drifted to the northeast and as the latter approach metamorphosis they migrate to the lower half of the water column and pass through the Friesian Islands to the nursery ground, from which they diffuse away later to join the adult stock on the feeding ground.

\section{DISCUSSION}

There are several links between the natural history of plaice and physical processes. Plaice spawn over an area broad enough to ensure that the patch of eggs or larvae retains its identity against the diffusive processes of the sea throughout the larval drift towards the nursery ground. As the larvae grow they move to the lower part of the water column and hence their speed of migration on the larval drift is much less than the surface drift. The hydrodynamic mechanism in the Texel Gate, which transfers larvae to the coastal waters, is crucial and in the course of time the larval drift has been averaged in timing and direction to take advantage of it. Most survivors reach the nursery ground in the Wadden Sea. On the nursery ground, the 0 -group plaice grow at maximal rate implying no food limitation in the rich coastal nursery with, as a consequence, a relatively low predation rate (Zijlstra et al. 1982). They diffuse away from the nursery ground towards the deeper water where they feed.

The nursery ground of the Flamborough spawning group lies on the Yorkshire coast, for example, in Filey Bay (Lockwood 1974). Zijlstra (1972) showed that there was an abundant nursery in the estuary of the Scheldt (Netherlands), about $125 \mathrm{n}$ mile downstream of the centre of the spawning ground in the eastern English Channel (see Fig. 6). That is the same distance between the centre of spawning in the Southern Bight and the Wadden Sea nursery. That distance downstream of the centre of spawning in the German Bight suggests a possible nursery on the Danish coast, north of $56^{\circ} \mathrm{N}$. The larval drift forms the geographical base to the circuit of migration. If the larval drifts are as diverse as suggested above, then the spawning groups must remain distinct and isolated.

De Veen (1978) tagged fish on each of the 4 spawning grounds and showed that the charts of recoveries on the feeding grounds differ markedly, although they do overlap. For example, the fish from the Southern Bight did not migrate further north than the Dogger Bank; the northern boundaries of the Flamborough and German Bight groups lie as far north as Aberdeen and the Skagerrak, respectively. This geographical separation is really a consequence of the distance between spawning grounds. But the most remarkable result of de Veen's work was that fish displaced from their spawning ground of origin moved back to it to some degree after 4 to 6 mo. In contrast, those that were not displaced remained in a broad distribution about their own spawning ground. Thus, a tendency to home was demonstrated and combined with the geographical separation provides a basis for the relative isolation of the spawning groups.

On the migration to and from the spawning ground plaice make use of tidal streams to travel for 100 to 150 $n$ miles. Some problems remain, for example, how does the migration start and stop? Harden Jones (1980) suggests, for instance, that when Low Water Slack and moonrise occur at sunset the maturing fish might be entrained on the subsequent southbound flood tide. When the spents return on the ebb they might start their northbound migration when High Water Slack occurs at sunrise. Arnold \& Cook (1984) suggested that slack water might be detected by lack of turbulence or lack of noise. Another problem is how the fish locate the spawning ground; Harden Jones (1984a), following Hasler (1966), suggested that freshwater springs in the sea might exude distinctive molecules. But, despite these illuminating suggestions we do not yet know how the plaice start to migrate and how they stop. Further, we do not know how the plaice detect the right tide on which to rise into midwater or on which to stay on the seabed.

There are 4 factors of importance. First, larval drifts, nursery grounds, feeding grounds and spawning grounds are geographically distinct. Second, larvae are drifted in the residual current under the influence of the wind and they use selective tidal transport to enter the nursery ground from the Dutch coastal water Third, selective tidal transport allows the fish to move rapidly on migration to and from the spawning ground. Fourth, the plaice tend to home towards their ground of first spawning. All 4 factors will tend towards the isolation of each spawning group.

Animals are adapted to their physical environment 
and stabilize their numbers in the face of its variability. Recruitment of plaice to the managed stock (southern North Sea and eastern English Channel) can be predicted from numbers caught in the shrimp fishery carried out in the plaice nursery along the German coast in early summer directly after metamorphosis (Rauck \& Zijlstra 1978). Evidence from Wimpenny (1953) suggests that recruitments are common to the spawning groups in the German Bight and the Southern Bight. There is a little evidence that recruitment can be predicted in the late larval stage just before metamorphosis (van der Veer 1986) as plaice enter the Wadden Sea from the Southern Bight spawning. But, density-dependent mortality by shrimp predation occurs at settlement (van der Veer 1986). Although such mortality appears to be enough to regulate the plaice population in the southern North Sea (Cushing 1988), there must be another mechanism by which the population can regulate itself without an external agency, i.e. the shrimps. But the most important point is that the vital processes by which recruitment is established occur in a short time just before and just after metamorphosis.

De Veen's work $(1961,1962)$ on the dispersion of tagged fish from the spawning ground, showed that the exchange between 3 spawning groups is low in the southern North Sea (German Bight, Southern Bight and Flamborough): 1 to $2 \% \mathrm{yr}^{-1}$. To that extent, each spawning group is isolated. The maturing adults use the tides to migrate to the spawning grounds in the Southern Bight and the spent fish use them to return to the feeding ground. Because the fish can start and stop either migration in a regular manner, the time and position of spawning remain the same from year to year. From that position the larvae are drifted to the nursery ground which is also in a fixed position, but which may be visited sporadically by fish originating from the females of a different spawning (the evidence of limited exchange is established from the tagging experiments). The diffusion from nursery ground to feeding ground puts the first time spawners in place to migrate to their spawning ground. The sequence of events in time and place may provide the isolation for the spawning group in the Southern Bight through the circuit of migration. Also it provides the mechanism by which the stock is retained within the region in which it lives. It should be pointed out that the arrangement of events in the other spawning groups is not yet well enough known to make good comparisons.

In addition to the 3 spawning groups in the southern North Sea, there are 2 in the English Channel and 1 in the Moray Firth in the northern North Sea. Purdom \& Wyatt (1969) found a genetic difference between Irish Sea plaice and those in the southern North Sea. The units of hydrographic containment are much smaller than those between which there is genetic difference. To maximize genetic variability, a number of spawning groups is needed between which the exchange is low.

The 3 spawning groups in the southern North Sea and the eastern English Channel comprise the present unit of management. Because the 3 groups mix on their feeding grounds and individuals of the 3 groups cannot be distinguished there, smaller management units are impracticable. In any case the only reason for the smaller groups of management would be that the series of recruitments were distinct, for which there is no evidence; indeed, as indicated above on slight evidence, the recruitments to the 2 groups Southern Bight and German Bight may be common.

Fish are linked to the physical environment in 2 ways, through the sensory input of individuals and by the averaging of physical factors in time. As the larvae grow older, they respond to lower levels of irradiance but the use of the passages across the coastal water boundary is a discovery of great importance to the Southern Bight spawning group, because these lead to the entrances to the Wadden Sea, the nursery ground. The maturing adults may respond to combinations of sunset, full moon and Low Water Slack to start their spawning migrations and there may be analogous cues to stop the southerly migration in order to spawn.

In the same way the direction of the tidal streams determines the nature of the migration circuit. Indeed, those in the German Bight form a distinct spatial structure and the separation of the 2 spawning groups, German Bight and Southern Bight, may depend upon this difference. In quite another way, spawning is timed to average the long-term variability in the time of onset and the duration of the spring outburst in the Southern Bight; if recruitment is formed towards the end of the larval drift and if the population is stabilized by the time of settlement, this average is of considerable importance.

The stock is retained in the southern North Sea between the Dogger Bank and the Straits of Dover, an area dominated by tidal streams. There are summer fronts in the Dogger region but none to the south. The spawning group in the Southern Bight of the North Sea is probably retained there by behavioural mechanisms in the regular structure of the tidal streams. Selective tidal stream transport might be expected to be important in waters $<100 \mathrm{~m}$ in depth. The spawning group is retained within the area by behavioural mechanisms and depends upon the existence of the tidal streams. There is no reason why analogous mechanisms should not be found wherever there is a regular current system. 


\section{LITERATURE CITED}

Arnold, G. P., Cook, P. H (1984). Fish migration by selective tidal transport; first results with a computer simulation model for the European Continental Shelf. In: McLeave, J, D., Arnold, G. P., Dodson, J. J., Neill, W. H. (eds.) Mechanisms of migration in fishes. Plenum Press, New York, $p$. $227-262$

Beverton, R. J. H., Holt, S. J. (1957). On the dynamics of exploited fish populations. Fish. Invest. London Ser 2. 19: $1-533$

Beverton, R. J. H., Lee, A. J. (1965). Hydrographic fluctuations in the North Atlantic Ocean and some biological consequences. In: Johnson, C. G., Smith, L. P. (eds.) The biological significance of climatic changes in Britain. Academic Press, London, p. 79-107

Creutzberg, F. (1961). On the orientation of migrating elvers (Anguilla vulgaris Turt.) in a tidal area. Neth. J. Sea Res. 1: $257-338$

Creutzberg, F. A., Eltink, A. T. G. W., van Noort, G. J. (1978). The migration of plaice larvae Pleuronectes platessa into the western Waddensea. In: McClusky, D. S., Berry, A. J. (eds.) Physiology and behaviour of marine organisms. Pergamon Press, Oxford, p. 243-251

Cushing, D. H. (1968). Fisheries biology. Univ. Wisconsin Press, Madison

Cushing, D. H. (1969). The regularity of the spawning season in some fishes. J. Cons. int. Explor. Mer 33: 81-97

Cushing, D. H. (1972). The production cycle and the numbers of marine fish. In: Edwards, R. W., Garrod, D. J. (eds.) Conservation and productivity of natural waters. Pergamon Press, Oxford, p. 213-232

Cushing, D. H. (1973). The natural regulation of fish populations. In: Harden Jones, F. R. (ed.) Sea fisheries research. Elek, London, p. 399-411

Cushing, D. H. (1975). Marine ecology and fisheries. Cambridge University Press, Cambridge

Cushing, D. H. (1982). Climate and fisheries. Academic Press, London

Cushing, D. H. (1988). The study of stock and recruitment. In: Gulland, J. A. (ed.) Fish population dynamics, 2nd edn. John Wiley, Chichester p. 83-104

Dickson, R. R., Reid, P. C. (1983). Local effects of wind speed and direction on the phytoplankton of the Southern Bight. J. Plankton Res. 5: 441-457

Dietrich, G. (1954). Verteilung, Ausbreitung und Vermischung der Wasserkörper der südwestlichen Nordsee auf Grund der Ergebnisse der 'Gauss'-Fahrt im Februar-März, 1952. Ber. dt. wiss. Komm. Meeresforsch. N.F.Bd 32: 104-29

Gieskes, W. W C., Kraay, G. W. (1977). Continuous Plankton Records: changes in the plankton of the North Sea and its eutrophic Southern Bight from 1948 to 1975. Neth. J. Sea Res. 11: 334-364

Graham, M. (1956). The plaice. In: Graham, M. (ed.) Sea fisheries, Edward Arnold, London, p. 332-371

Greer-Walker, M., Harden Jones, F. R., Amold, G. P. (1978). The movements of plaice (Pleuronectes platessa L.) tracked in the open sea. J. Cons. Int. Explor. Mer 38: 58-86

Harden Jones, F. R. (1968). Fish migration. Edward Arnold, London

Harden Jones, F. R. (1980). The migration of plaice (Pleuronectes platessa) in relation to the environment. In Bardach, J. E., Magnuson, J. J., May, R. C., Reinhart, J. M. (eds.) Fish behavior and its use in the capture and culture of fishes. ICLARM Conf. Proc. 5, Manila p. 383-399

Harden Jones, F. R. (1984a). A view from the acean. In: McCleave, J. D., Arnold. G. P., Dodson, J. J., Neill, W H. (eds.) Mechanisms of migration in fishes. Plenum Press, New York, p. 1-27

Harden Jones, F. R. (1984b). Could fish use inertial clues when on migration? In: McCleave, J. D., Arnold, G. P., Dodson, J J., Neill, W. H. (eds.) Mechanisms of migration in fishes. Plenum Press, New York, p. 67-78

Harden Jones, F. R., Greer Walker, M., Arnold, G. P. (1978). Tactics of fish migration in relation to migration strategy and water circulation. In: Charnock, H., Deacon, G. (eds.) Advances in oceanography. Plenum Press, New York, p. 185-207

Harding, D., Nichols, J, Tungate, D. S. (1978). The spawning of plaice (Pleuronectes platessa L.) in the Southern North Sea and English Channel. Rapp. P.-v. Cons. int. Explor. Mer 172: 102-113

Harding, D., Talbot, J. W. (1973). Recent studies on the eggs and Iarvae of the plaice (Pleuronectes platessa L.) in the Southern Bight. Rapp. P.-v. Cons. Int. Explor. Mer 164: $261-269$

Heincke, F. (1913). Untersuchungen über die Scholle, Generalbericht. I Schollenfischerei und Schonmaßregeln. Vorläufige kurze Übersicht über die wichtigsten Ergebnisse des Berichts. Rapp. P.-v. Cons. int. Explor Mer 16: 1-70

Hasler, A. D. (1966). Underwater guideposts. Univ. Wisconsin Press, Madison, p. 1-155

Lockwood, S. J. (1974). The settlement, distribution and movements of 0-group plaice, Pleuronectes platessa (L.) in Filey Bay, Yorkshire. J. Fish. Biol. 6: 465-477

Mitson, R. B., Storeton-West, T J. (1971). A transponding acoustic fish tag. The Radio and Electronic Engineer 41 : $483-489$

Mitson, R. B., Storeton West, T. J., Pearson, N. D. (1982). Trials of an acoustic transponding fish to compass. Biotelemetry 9: $69-79$

Purdom, C. E., Wyatt, T (1969). Racial differences in Irish and North Sea plaice (Pleuronectes platessa L.). Nature, Lond. 222: $780-788$

Rauck, G. (1977). Two German plaice tagging experiments (1970) in the North Sea. Arch FischWiss. 28: 57-64

Rauck, G., Zijlstra, J. J. (1978). On the nursery aspects of the Wadden Sea for some commercial fish species and possible long term changes. Rapp. P.-v. Cons. Int. Explor. Mer 172: 266-275

Rijnsdorp, A. D., Stralen, MI van (1982). Selective tidal migration of plaice larvae in the Oosteschelde and the western Waddensea. Coun. Meet. int. Coun. Explor Sea. C.M.ICES/G: $1-31$

Simpson, A. C. (1956). The pelagic phase. In: Graham, M. (ed.) Sea fisheries. Arnold, London, p. 207-50

van der Veer, H. (1986). Immigration, settlement and density dependent mortality of a larval and post-larval 0-group plaice (Pleuronectes platessa) population in the western Wadden Sea. Mar. Ecol. Progr. Ser. 29: 223-236

de Veen, J. F. (1961). The 1960 tagging experiments on mature plaice in different spawning areas in the Southern North Sea. Coun. Meet. int. Coun. Explor. Sea C.M.-ICES Near Northern Seas 44: 1-7

de Veen, J. F (1962). On the subpopulations of plaice in the Southern North Sea. Coun. Meet. int. Coun. Explor Sea C.M.-ICES Near Northern Seas 94

de Veen, J. F. (1978). On selective tidal transport in the migration of North Sea plaice and other flatfish species. Neth. J. Sea Res, 12(2): 115-147

de Veen, J. F., Boerema, L. K. (1959). Distingurshing southern North Sea populations of plaice by means of otolith characteristucs Coun. Meet int. Coun. Explor. Sea C.M.-ICES Near Northem Seas Comm. Paper 91. 1-5 
Visser, M. P. (1971). Some features of the North Sea oceanography near Texel. Coun. Meet. int Coun. Explor Sea C.M.-ICES: $41.1-3$

Visser, M. P. (1977). Oceanografische omstandigheden in het zeegebiet nabij Texel. Wetenschappelijk Rapport 77-1 Kon. Ned. Met. Inst. 1-18

Wimpenny, R. S. (1953). The plaice, being the Buckland lectures for 1949. Edward Arnold, London

This review was submitted to the editor
Zijlstra, J. J. (1972). On the importance of the Wadden Sea as nursery area in relation to the conservation of the Southern North Sea fishery resources. Symp. Zool. Soc. Lond. 29: $233-258$

Zijlstra, J. J., Dapper, R., Witte, J. Ij. (1982). Settlement, growth and mortality of post larval plaice (Pleuronectes platessa L.) in the western Waddensea. Neth. J. Sea Res. 15: $250-272$

Manuscript first received: January 31, 1989

Revised version accepted: August 16, 1989 